\title{
Translocation of Blue and Gold Macaw Ara ararauna into its historical range on Trinidad
}

\author{
DAVID A. OEHLER, DAVID BOODOO, BERNADETTE PLAIR, KRISTINE \\ KUCHINSKI, MARK CAMPBELL, GUPTE LUTCHMEDIAL, SHAM \\ RAMSUBAGE, EDWARD J. MARUSKA and STEVE MALOWSKI
}

\begin{abstract}
Summary
New World parrots are declining throughout their range. Blue and Gold Macaw Ara ararauna was extirpated from the island of Trinidad in the late 1960s through anthropogenic processes. The Cincinnati Zoo \& Botanical Garden is assisting the Wildlife Section of the Forestry Division, Trinidad on a mission to restore the species into its historical range within the Bush-Bush Sanctuary in the Nariva Swamp. The Sanctuary has been protected by the government of Trinidad and is the home of the endangered Red-bellied Macaw Ara manilata and West Indian Manatee Trichechus manatus. Zoo and Wildlife personnel participated in three separate releases, beginning in December 1999 through to March 2000. The initial release consisted of an identical sex group of macaws followed by two additional releases of pairs/groups of birds. Of 18 Blue and Gold Macaws, 14 were released into the Nariva Swamp and are currently being monitored by the Wildlife Section, Zoo personnel and surrounding community. Translocation of wild populations of parrots has proven to be a viable solution to restocking wild populations that have been regionally extirpated.
\end{abstract}

\section{Introduction}

The Wildlife Section of the Forestry Division, Trinidad, and the Cincinnati Zoo \& Botanical Garden embarked on a mission to restore Blue and Gold Macaws Ara ararauna into their historical range within the Nariva Swamp, southeastern Trinidad. Blue and Gold Macaws were endemic to the region prior to their extirpation through anthropogenic processes, e.g. over-collection of birds for the pet trade and pressures from agricultural interests.

Blue and Gold Macaw is listed under CITES Appendix II throughout most of its range, which presently consists of Panama south through Colombia and eastward to southern Venezuela, the Guianas, Brazil and Bolivia (Woolham 1987). These colourful macaws formerly occurred on Trinidad and apparently in Paraguay, Argentina and western Ecuador, where they are now extinct. Typical habitat within these regions is seasonally flooded várzea forest and gallery forest, Mauritia palm stands in savanna, and in the north-west portion of their range, deciduous forest away from water. Food items include seeds, nectar, flowers, fruit and / or petioles, pulp, arils, leaves, mesocarp and palm nuts (del Hoyo et al. 1997). 
Population densities of large macaws are normally estimated at 5-10 birds per square mile of forest ( 1 square mile $=259$ hectares), and they reproduce slowly, with populations usually increasing by about $15 \%$ annually (Munn 1994).

Of the nearly 140 species of parrots found in the New World, nearly one-third are considered at some risk of extinction, with the remaining two-thirds declining in numbers. These declines are a result of habitat destruction and exploitation for the pet trade (Collar and Juniper 1992). Blue and Gold Macaw formerly occurred in the Nariva Swamp on Trinidad, but disappeared in the 1960s in large part due to the collection of chicks by local hunters from nests in Mauritia and Cabbage Oreodoxa Palms in April and May (Belcher and Smooker 1936). Nevertheless, approximately 15 birds were observed in the vicinity of the Bush-Bush region in 1968 (Nottebohm and Nottebohm 1969, Bacon and Ffrench 1972, del Hoyo et al. 1997). Ten birds were observed in the Nariva Swamp in 1980, although these may have been escaped pets and have now disappeared. During the early 1980s, hundreds of Blue and Gold Macaws, derived from wild stock collected elsewhere, were transferred to Trinidad and Paraguay for exportation, leading to calls for formal protection (Ridgely 1981). A resent census of psittacine taxa in the Nariva Swamp in 1998 documented a population of 136 Red-bellied Macaws, 224 Orange-winged Parrots Amazona amazonica and an undetermined number of Green-rumped Parrotlets Forpus passerinus. Red-bellied Macaws and Orange-winged Parrots utilized Roystonea and Mauritia palms for roost and nest sites, and fed on fruit produced throughout the year, (excluding the dry season) by Roystonea palms from July to December, and Mauritia from October to January (Bonadie and Bacon 2000).

Feral populations of parrot species derived from wild-caught populations have become established in urban environments that provide certain levels of security. Translocation of parrots has been attempted in several instances, some successfully, while others are still under way and must be evaluated later. Programmes to relocate wild populations of the endangered Kakapo Strigops habroptilus are being conducted by the New Zealand government and have shown promise (King 1977-2979, Merton and Empson 1989). Another programme in New Zealand successfully established Red-crowned Parakeet Cyanoramphus novaezelandiae on Tiritiri Matanga and Cuvier Islands from captive stock (Taylor 1985). Bluethroated Conures Pyrrhura cruentata have been established in the Tijuca National Park in Guanabara, Brazil, through translocation (Silva 1989). Captive-reared Yellow-shouldered Parrots Amazona barbadensis have been successfully introduced to Margarita Island, Venezuela after a year long acclimation period, into an area occupied by an established wild population of the same taxon (Sanz and Grajal 1998). The most applicable project involved the release of bonded pairs of Blue and Gold Macaws in Panama. These macaws were released as pairs and established a growing population within two years of release (Susan Clubb pers. comm.). The releases of Thick-billed Parrots Rhynchopsitta pachyrhyncha in Arizona, U.S.A., achieved varied results, with wild-caught translocated adults demonstrating survival and reproductive capabilities, while captive-reared and in particular longer-term captive birds demonstrated a poor survival rate (Snyder et al. 1994). While these projects have been successful, others, such as attempts to establish new populations of Uvea Horned Parakeet Eunymphicus cornutus uvaeensis from Uvea, Loyalty Islands, on other islands, Vasa Parrots Coracopsis 
vasa on Réunion, Mascarene Islands and Grey-headed Lovebirds Agapornis cana on Rodriguez, Mauritius, the Comoro Islands, the Seychelles, Zanzibar and Mafia Island, have shown limited success or have failed altogether (Delacour 1966, Forshaw 1989, Long 1981).

Where populations of wildlife have been extirpated locally, but the limiting factors causing extirpation have been improved, it may be feasible to re-establish populations from other sources. This can greatly increase a species' security by increasing the number and geographical distribution of its populations (Soulé 1987). In order for such a translocation project to succeed, preparations prior to the transfer of stock should be conducted. For parrot translocations, habitat management must ensure that the resources vital to the species' survival are available, such as accessibility of nest sites and food. The use of wild-caught parrots as release candidates offers advantages over captive-reared birds, including individuals with the capacity for social integration, foraging skills, ability to select roosting sites, and predator avoidance (Snyder et al. 1994, Abramson et al. 1995, Wiley et al. 1992). Additional preparations should be performed, including gaining the co-operation of countries involved, medical screening of individual birds, and ensuring the release site is stable and protected. Educational programmes fostering national pride to promote species preservation, particularly within limited areas such as Caribbean communities have demonstrated great success and are a crucial element of a release programme (Sanz and Grajal 1998, Butler 1992). Selection of numerous birds at a relatively even sex ratio, especially bonded pairs, is more likely to result in success (Griffith et al. 1989, Schubot et al. 1992). Subsequent to the initial release, long-term monitoring of the parrots must be established to identify causes of mortality, reproductive success or failure and general condition of the group as a whole.

\section{Study area and methods}

Working in conjunction with the Centre for the Rescue of Endangered Species of Trinidad \& Tobago (CRESTT), the Forestry Division approached the Cincinnati Zoo in 1993, for assistance in re-establishing a population of Blue and Gold Macaws on Trinidad (Figure 1). The Forestry Division maintained a captive group of macaws and was given training in the proper husbandry protocols. In the future, this group of birds will be maintained for educational purposes and as future stock to augment wild populations. Aerial and ground surveys of the Nariva Swamp were conducted to assess damage caused by illegal rice farming as well as extensive fires during the 1995 dry season. This survey concluded that the core habitat remained intact and continued to provide ample supplies of the Moriche Palms, a potential food source for the macaws, and suitable nest sites.

Initial efforts to protect Nariva Swamp began via a manatee conservation effort funded by the local Rotary Club. Additional protection was granted in 1993 when the area was declared a prohibited area under the Forest Act, Chapter 66:01, which includes the Bush-Bush Wildlife Sanctuary, encompassing 1,528 ha. BushBush had been previously declared a Wildlife Sanctuary in 1968 for its undisturbed hardwood forests containing 171 species of birds and numerous vertebrate and invertebrate species (Bacon and Ffrench 1972). This protection included monitoring of the area by Forestry Rangers and community members. 


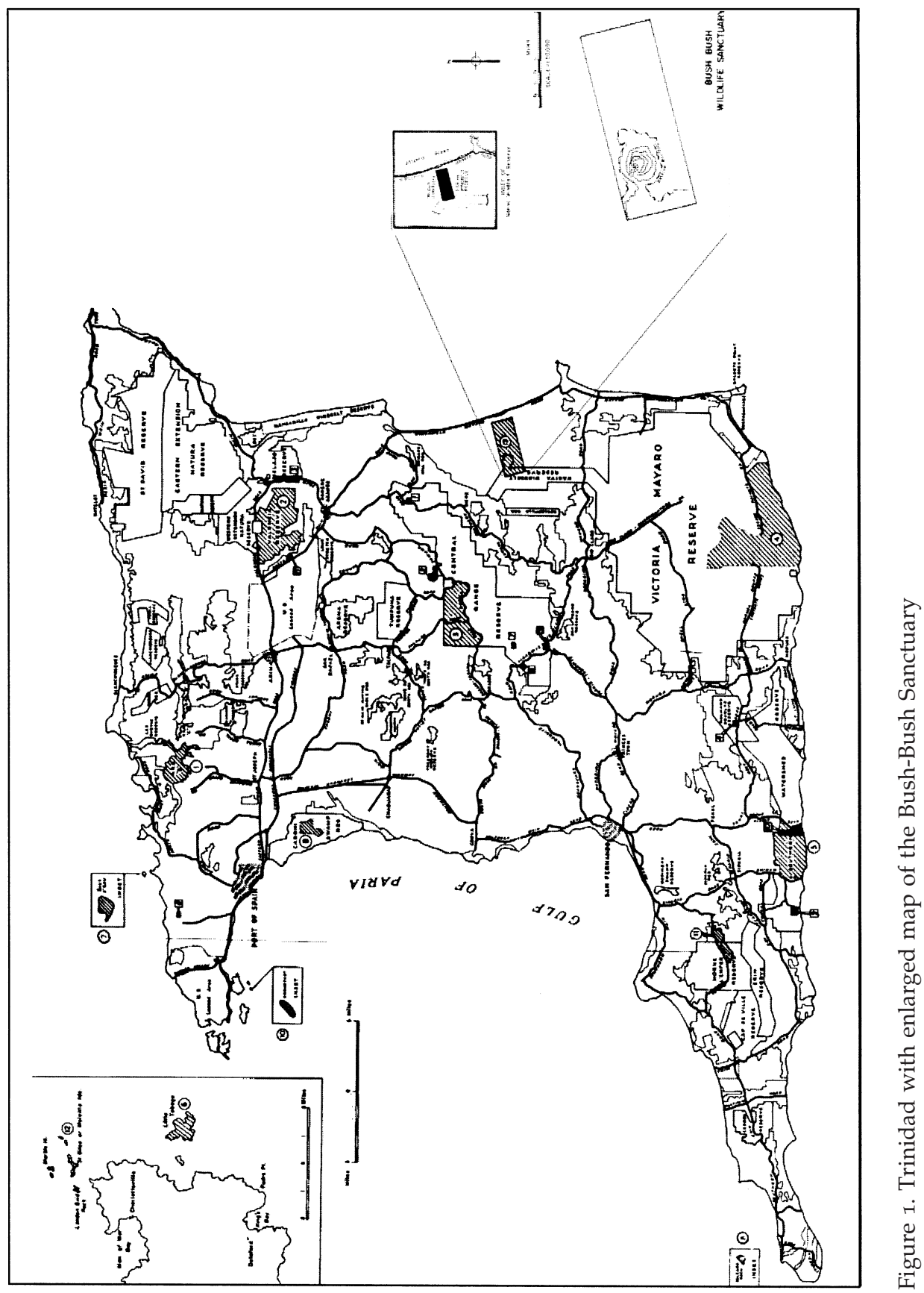


Formal safety measures were initiated in 1999 when Blue and Gold Macaw was granted "Protected" status under the Conservation of Wildlife Act, Chapter 67:01. This status provided for the protection of any macaws released onto Trinidad and required the registration of facilities housing captive populations.

In August 1999, a team of veterinarians and Zoo personnel were dispatched to Georgetown, Guyana to procure, surgically sex and examine a number of Blue and Gold Macaws that had been designated for export to Italy. The group of macaws had been collected from the wild two weeks previously in an area 95 $\mathrm{km}$ south of Georgetown. Eighteen birds, representing nine potential pairs, were identified for transfer from Guyana to Trinidad. The medical examination included testing for possible pathogens, such as papillomavirus, which causes persistent infections and manifests itself following stressful events, posing health concerns for other indigenous parrot species on Trinidad (White and Fenner 1987). Samples were sent to the U.K. for testing for, inter alia, Newcastle's disease, psittacosis and avian influenza. Newcastle's disease is a strain of paramyxovirus that is vertically transmitted through faecal and respiratory secretions, resulting in death. Avian influenza, another viral disease, demonstrates clinical signs in psittacines including lethargy, diarrhoea, respiratory problems and death (Rupley 1997). Psittacosis is a highly contagious disease caused by a bacterial infection (Chlamydia psittaci) that is a common ailment in psittaciformes with New World parrots being more susceptible than Australian and African parrots (Gerlach 1993, 1994, Tully 1993). After undergoing mandatory quarantine procedures, the group of parrots was transferred to Trinidad and placed in a secure flight, constructed within Nariva Swamp.

An extensive survey of the vegetation within a $1 \mathrm{~km}$ radius of the release site was conducted by the rangers of the Wildlife Section and Cincinnati Zoo personnel. This survey reconfirmed that an ample supply of food would be available to the macaws upon their release. The list of fruiting vegetation included Moriche Palm Mauritia setigera, Hog Plum Spondias mombin, Wild Cashima Rollinia exsucca, Mahoe Sterculia caribaea, Puni Pithecellobium jupunba, Cocorite Palm Maximiliana elegans, and Balata Manilkara bidentata, which were distributed widely throughout the surveyed area. Serrette Byrsonima coriacea and Cajuca Virola surinamensis were established within $50 \%$ of the area, Black Olivier Terminalia amazonia and Lagoon Ceder Licania spp. within $25 \%$ of the area, while Wild Guava Myrcia leptaclada, Bois Bande Parinari campestris and Hairy Pois Doux Inga venosa were limited to less than $20 \%$ of the surveyed region.

Cincinnati Zoo personnel assisted in the transfer of the macaws on 9 November 1999. Each macaw was examined to ensure good general condition and proper growth of the flight feathers. The primaries of each had been clipped by the trappers in Guyana as standard procedure during their capture. Two or three clipped feathers were pulled for regrowth prior to their arrival in Trinidad, leaving guard feathers to protect the comparatively delicate blood feathers that would develop.

The Wildlife Section of Trinidad began providing security during the day with additional personnel from the Manatee Conservation Programme patrolling the area at night. All of the macaws remained the property of the Cincinnati Zoo and an announcement was circulated to this effect. With this ownership came the knowledge that the Zoo had placed transponder chips (Trovan brand, 
Stephen Clark Ltd, Alva, Clackmannan FK12 5JJ, U.K.) in each bird that would provide positive identification of the birds. Transponder chips consisted of a computer chip with a unique identification code, with a self-contained power source that could not be removed. This acted as a deterrent to anyone who planned to capture birds in the future.

An educational programme was launched in conjunction with the release of the macaws. This programme was developed utilizing the endangered Trinidad Piping Guan Pipile pipile conservation programme as a model. Additional graphics will be produced and installed at the Wildlife Section's propagation centre and the Emperor Valley Zoo, Trinidad describing the project and the natural history of Blue and Gold Macaw.

On 12 December 1999, Cincinnati Zoo personnel and Wildlife officers began observations of the colony of macaws within the release enclosure. Evidence of pair bonding was observed, meaning that the soon-to-be-released male macaws would be further inclined to establish territories near the captive females. Final physical examinations of the birds would be conducted upon capture and provision of food items adjacent to the release enclosures was prepared. On 14 December 1999, six male macaws were released from their enclosure. One individual did not appear to be in proper condition to maintain long periods of flight, was reluctant to leave the area and was recaptured and returned to the enclosure. The five remaining males dispersed throughout the swamp and, while not directly observed at all times, their vocalizations were heard for several days after the release.

On 13 January 2000, a further two male and five female Blue and Gold Macaws were examined and released. This group consisted of two bonded pairs, a female that was bonded with a non-flighted male and three individuals that had not been observed demonstrating pairing behaviour. Two males and four females were not released due to the lack of primary feather regrowth, rendering each flightless.

The Forestry Division developed a route travelled three times per week, to visit outlying communities. Observations, made by local villagers were plotted on a map to determine general habits of the flock and individual macaws. Such community-based monitoring of the Nariva Swamp area was a derivative of the Fire Prevention and Suppression Plan utilized by the Trinidad Forestry Division. The villages of Kernahan, Plum Mitan, Biche and Manzanilla were critical components of the fire prevention plan and macaw monitoring efforts. Daily observations were conducted by Forestry personnel and this information was incorporated into the overall dataset. Cincinnati Zoo personnel travelled to the release site on 13 March 2000 to assist in obtaining further data on the flock, including the search for active nesting behaviour and to release individual macaws, held within the release enclosure, which had regained the capacity for flight.

On 15 March 2000, a further pair of macaws was determined to be in proper condition for release. This pair was separated from the remaining birds, held in the pre-release enclosure, and released into the Nariva Swamp. Four macaws either demonstrated insignificant or no regeneration of the effected primary feathers and were transferred to a communal enclosure, at a private facility, for propagation or future release. 


\section{Results}

Fourteen Blue and Gold Macaws were released over a three-month period (Table 1). Three of the original five males were not observed six days post-release and were assumed to have died. Due to lack of flight capabilities and entrapment in local aviaries, one male and one female were recaptured and returned to the acclimation enclosure. Four macaws remained unreleasable and were placed into propagation facilities. Five male and six female macaws have now established in the Nariva Swamp and the surrounding area.

\section{Release I: 15 December 1999}

Six male Blue and Gold Macaws were released within close proximity of the acclimatization enclosure on 15 December 1999, with one individual recaptured on 17 December and returned to the enclosure (see above). Within 48 hours, four macaws were observed near or at the release site taking food items provided by the project personnel. By 20 December, two of the birds had progressed to Plum Mitan and the village of Biche, 14 and $13 \mathrm{~km}$ from the initial release site. These individuals were observed actively foraging within these areas. Relatively few observations were made until two individuals were located along the south-east border of the Sanctuary on 12-23 January 2000 when captive pairs of macaws were used to induce auditory contact with the released birds. Observations on the remaining three males were non-existent (Figure 2).

\section{Release II: 13 January 2000}

On 13 January 2000 two males and five female Blue and Gold Macaws were released in a similar manner. Four of these birds were observed approximately $30 \mathrm{~m}$ above the forest canopy and were flying distances of approximately $10 \mathrm{~km}$ within 24 hours of the release. Two individuals returned to the release enclosure,

Table 1. Position of sightings of translocated Blue and Gold Macaws in December 1999, and January, February, March, June, July and August 2000, by Wildlife Rangers and local residents of the area surrounding the Nariva Swamp, Trinidad.

\begin{tabular}{|c|c|c|c|c|c|c|c|}
\hline Location & $\begin{array}{l}1999 \\
\text { Dec }\end{array}$ & $\begin{array}{l}2000 \\
\text { Jan }\end{array}$ & $\begin{array}{l}2000 \\
\text { Feb }\end{array}$ & $\begin{array}{l}2000 \\
\text { Mar }\end{array}$ & $\begin{array}{l}2000 \\
\text { Jun }\end{array}$ & $\begin{array}{l}2000 \\
\text { Jul }\end{array}$ & $\begin{array}{l}2000 \\
\text { Aug }\end{array}$ \\
\hline Bush-Bush, release site $<2 \mathrm{~km}$ & $\times$ & $\times$ & & $\times$ & $\times$ & $\times$ & $\times$ \\
\hline Bush-Bush, release site $>2 \mathrm{~km}$ & $\times$ & $x$ & & & $\times$ & $\times$ & $\times$ \\
\hline Kernahan Village, $9 \mathrm{~km}$ from release site & & & & $\times$ & $\times$ & $\times$ & $\times$ \\
\hline Brigand Hill, 10 km from release site & $\times$ & & $\times$ & & & & \\
\hline Biche Village, $13 \mathrm{~km}$ from release site & $\times$ & & & & & & $\times$ \\
\hline Plum Mitan, $14 \mathrm{~km}$ from release site & $\times$ & & $\times$ & $x$ & & $\times$ & $x$ \\
\hline North Manzanilla, $16 \mathrm{~km}$ from release site & & $\times$ & $\times$ & $\times$ & $\times$ & $\times$ & $\times$ \\
\hline Central Range Reserve, $25 \mathrm{~km}$ from release site & & & & & & $\times$ & $\times$ \\
\hline Pt Gauleota, $26 \mathrm{~km}$ from release site & & & $\times$ & & & & \\
\hline Valencia Reserve, $27 \mathrm{~km}$ from release site & & & $\times$ & & & & $\times$ \\
\hline Cumuto, $31 \mathrm{~km}$ from release site & & & & & & $\times$ & $\times$ \\
\hline Mt Harris, $51 \mathrm{~km}$ from release site & & & $\times$ & & & & \\
\hline
\end{tabular}




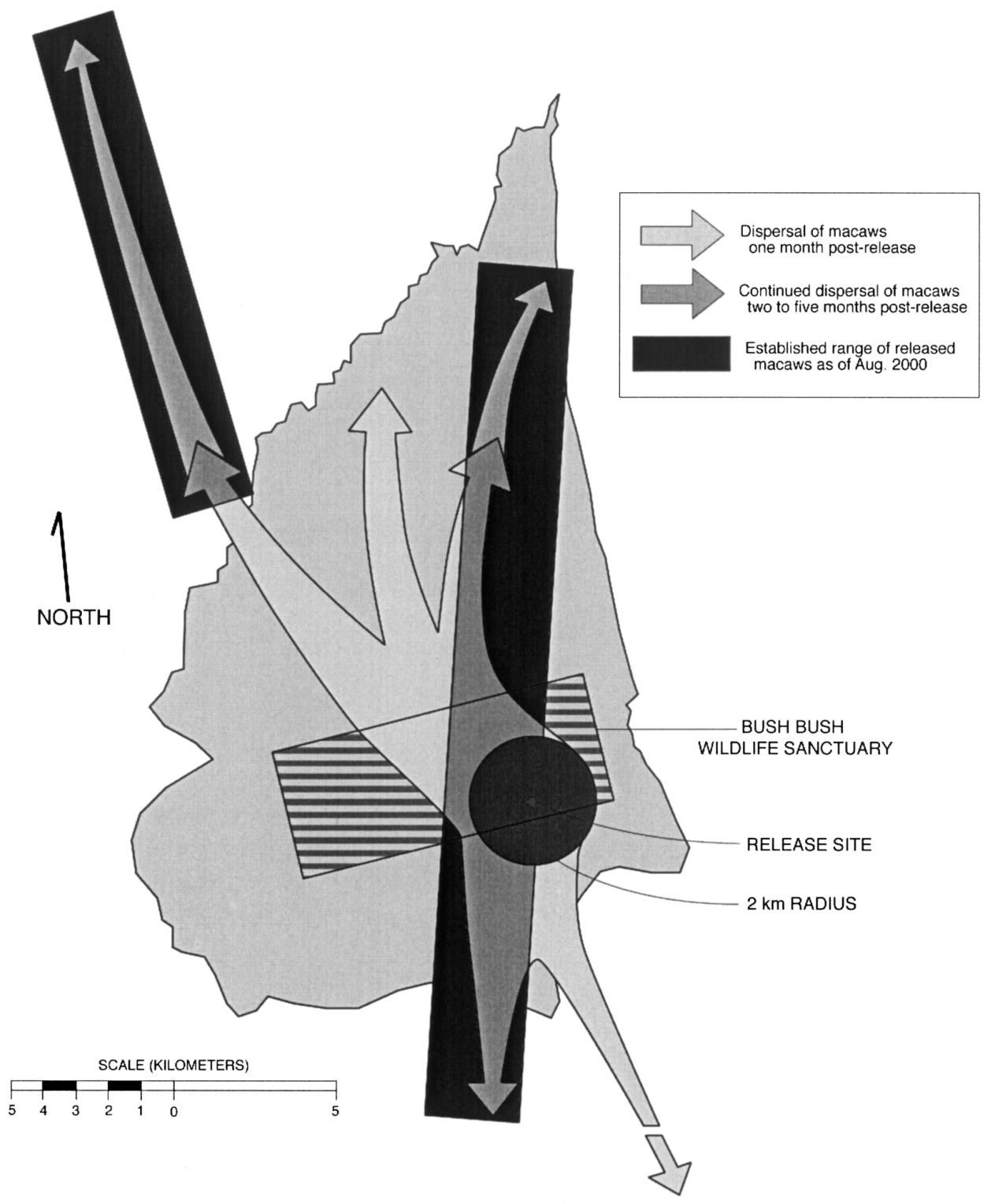

NARIVA SWAMP, TRINIDAD

Figure 2. Emigration of Blue and Gold Macaws from the release site, within the Bush-Bush Wildlife Sanctuary, Trinidad. A majority of the initial dispersal of macaws, within one month of release, remained within a $16 \mathrm{~km}$ radius of the release site. Subsequent dispersal patterns, at 2-5 months, demonstrated a pattern that would develop into the fixed range of two groups of macaws: the western population, consisting of four birds, and the eastern population of six birds, observed on a regular basis. 
on a daily basis, and perched next to the wire fence of the cage in close proximity to individuals that remained in captivity. This group remained near the acclimatization enclosure for four days, perching near the enclosure and taking the provided food items. Continued observations of the flock were reliant mainly on reports of birds in flight by the villagers of the surrounding area.

Within one month of this second release two macaws were observed as they flew each morning from the Valencia Reserve, located $27 \mathrm{~km}$ north of Bush-Bush, to Mt Harris, an additional $24 \mathrm{~km}$ north-west. Two other macaws had settled into the region of Manzanilla, located approximately $16 \mathrm{~km}$ north of the release site and were observed to be roosting and feeding on Moriche Palms. A single male journeyed south $26 \mathrm{~km}$ to Pt. Gauleota, Guyaguyare and sought refuge in a private aviary. Reports of this event were forwarded to the Wildlife Section of the Forestry Division and the bird was retrieved and placed in the enclosure at Bush-Bush.

During March 2000, two pairs of macaws were observed within a $10 \mathrm{~km}$ radius of the release site. These pairs were observed feeding on Moriche Palms or in transit throughout the day. No nesting activity had been noted by project personnel or the local community within the areas where the macaws had been located (Figure 2).

\section{Release III: 15 March 2000}

Two Blue and Gold Macaws were examined and released on 15 March 2000. These birds joined the individual Macaws that had established a range between Kernahan and the Manzanilla region (Figure 2).

\section{Other observations}

Local residents of Plum Mitan discovered a carcass of a Blue and Gold Macaw on 2 May 2000 and took the leg band and a portion of the dead body to officials of the Wildlife Section. The leg band corresponded to a male released in December 1999. Due to the condition of the remains, a cause and date of death could not be determined.

From June to August 2000, consistent sightings of macaws were reported by residents of the Kernahan Village, $9 \mathrm{~km}$ south-west of the release site. These six birds, travelling in pairs, have been observed flying from the Kernahan area north to the Manzanilla region by local tour operators. Four other individuals were observed traversing the areas between Plum Mitan and the Central Range Reserve in July and August 2000. A single bird was sighted near Valencia flying in an easterly direction on 2 August 2000. While easily observed during flights to and from roosting and foraging areas, these birds have also been monitored roosting on Royal Palms and Moriches Palms, both of which are possible food sources. These flight patterns are not in direct contact with those of the Redbellied Macaws, noted by project members, which originate in the area of Kernahan and extend to the south (Figure 2).

\section{Discussion}

Diminutive and/or fragmented populations are susceptible to stochastic difficulties such as inbreeding depression, loss of genetic variation and mutational 
compression. Future conservation of the Blue and Gold Macaws on Trinidad relies on maintaining the dynamic genetic and ecological processes identified within the historic parameters of the avian communities of the Nariva Swamp and the surrounding areas. Anthropogenic pressures stemming from possible exportation of macaws from Trinidad and encroachment of agricultural processes must be monitored by the Forestry Division, Trinidad. Addressing these factors through legislation and an ongoing educational programme by the coalition of participants involved in the initial release of macaws may diminish these pressures.

A major component ensuring the long-term success of this project is the sense of pride instilled into the communities of Trinidad. Enlisting local involvement in the initial release, monitoring of free-ranging macaws, using local rangers as project coordinators together with local funding has fostered a sense of ownership in the relocation project and in the conservation of the area on which the macaws are dependent. These components mirror those used in successful programmes elsewhere, such as on Margarita Island, Saint Lucia, Saint Vincent, the Grenadines and Dominica, with their corresponding Amazona parrots (Sanz and Grajal 1998, Butler 1992).

Mortality of $60 \%$ was incurred in the group of males from the first of the three releases. This group proved difficult to monitor with additional procedures being employed to determine specific position. No initial mortality has been encountered in the macaws released in groups of paired/bonded birds. Macaws released in this manner were also readily observed as they foraged for foodstuffs and in transit either to roosting areas or to foraging areas. Future projects involving the translocation of large macaws should evaluate these methods closely to ensure a higher degree of success. Due to the social nature of the large macaws, the number of pairs released at one time appears to have a direct impact on the overall success of the flock. Mortality within the birds released is inversely proportionate to the number of macaw pairs released at one time. Increased foraging success and predator avoidance while establishing territories enhance the rate of survivorship. Use of wild-caught stock enhances the success of foraging and roosting activities through the higher level of social integration achieved within the released individuals. The elapsed time required for individual, captive-bred macaws to acquire the necessary skills to survive would severely diminish their prospects of surviving the initial release.

Overall, these initial steps will serve as further support for translocation of wild populations as a viable solution to restocking or augmenting regionally extirpated populations. Continued long-term monitoring and augmentation of genetic material within this fragmented population must be addressed. Additional stock may be imported although this in itself inflicts pressures on existing populations. Soft-releases of captive progeny and the influx of genetic material they represent, similar to the introduction of captive-raised Yellow-shouldered Parrots may be a viable solution to this dilemma. A more intensive approach may be the use of the wild pairs as surrogate parents for eggs and chicks produced at the propagation areas operated by the Wildlife Section or similar facilities. Currently the translocated population of wild stock will serve as a base to the success of such soft releases. 
Continued monitoring of pre-existing populations of psittacine taxa should also be conducted to assess the impact of the Blue and Gold Macaw population on Red-bellied Macaw and Orange-winged Parrot. Increased competition for foodstuff and nest sites may have an adverse effect on these two populations. Depleted provisions of palm fruit may increase the incidence of all psittacine taxa using cocoa and other cultivated crops as alternative food sources, placing them in direct contact and competition with local farmers. Initial regulation of these populations may require augmented educational programmes and modified legislation to provide protection to the Orangewinged Parrot, now listed as a pest species which allows for hunting as a means of crop protection.

\section{Acknowledgements}

The Cincinnati Zoo would like to thank Mr Edward Thayer, The Endangered Parrot Trust and the over 100 Zoo members for their financial support in this endeavour. We would also like to mention the support and confidence that our Director Emeritus, Edward J. Maruska and the remainder of the Cincinnati Zoo's staff demonstrated toward the project members. It was indeed a pleasure to be associated with the wildlife officers of the Forestry Division, Wildlife Section of Trinidad, their enthusiasm and hard work made this project possible.

\section{References}

Abramson, J., Speer, B.L., and Thomsen, J.B. (1995) The large macaws, reintroduction as a conservation strategy for parrots. Pp. 261-262 in S.R. Beissinger and N.F.R. Snyder, eds. New World parrots in crisis. Washington, D.C.: Smithsonian Institution Press.

Bacon, P.R., and Ffrench, R.P. (1972) The Wildlife Sanctuaries of Trinidad and Tobago. Trinidad and Tobago: Wildlife Conservation Committee, Ministry of Agriculture, Lands and Fisheries.

Belcher, C. and Smooker, G.D. (1936) Birds of the Colony of Trinidad and Tobago. Ibis 6: $1-35$.

Bonadie, W.A. and Bacon P.R. (2000) Year-round utilization of fragmented palm swamp forest by Red-bellied macaws (Ara manilata) and Orange-winged parrots (Amazona amazonica) in the Nariva Swamp (Trinidad). Biol. Conserv. 95: 1-5

Bulter, P.J. (1992) Parrots, pressures, people, and pride. Pp. 25-46 in S.R. Beissinger and N.F.R. Snyder, eds. New World parrots in crisis. Washington, D.C.: Smithsonian Institution Press.

Collar, N.J. and Juniper, A.T. (1992) Dimensions and causes of the parrot conservation crisis. Pp. 1-24 in S.R. Beissinger and N.F.R. Snyder, eds. New World parrots in crisis. Washington, D.C.: Smithsonian Institution Press.

Delacour, J. (1966) Guides des oiseaux de la Nouvelle Caledonie et de ses Dependances. Neuchatel, Switzerland: Delachaux et Niestle.

del Hoyo, J., Elliot, A. and Sargatal, J. (1997) Handbook of the birds of the world, 4. Sandgrouse to cuckoos. Barcelona: Lynx Edicions.

Forshaw, J. (1989) Parrots of the world. 3rd revised edition. Australia: Willoughby, Lansdowne Editions.

Gerlach, H. (1993) The Biology of Chlamydia psittaci. Semin. Avian Exotic Pet Med. 2: 154256. 
Gerlach, H. (1994) Pp. 984-990 in Bacteria, avian medicine: principles and applications. Wingers Publishing, Inc. Lake Worth, Florida.

Griffith, B., Scott, J.M., Carpenter, J.W. and Reed, C. (1989) Translocation as a species conservation tool: status and strategy. Science 245: 477-480.

King, W.B. (1977-2979) Red data book, 2; Aves, part 2. Morges, Switzerland: International Union Conservation Nature and Natural Resources.

Long, J.L. (1981) Introduced birds of the world. London: David and Charles

Merton, D.V. and Empson, R. (1989) But it doesn't look like a parrot. Bird Internatn. 1: 60-72.

Munn, C. (1994) Macaw Conservation. Wildbird, April: 35-39.

Nottebohm, F. and Nottebohm, M. (1969) The parrots of Bush-Bush. Anim. Kingdom 72: 18-23.

Ridgely, R.S. (1981) The Current distribution and status of mainland Neotropical parrots, conservation of New World parrots; Proceedings of the ICBP Parrot Working Group Meeting, pp. 242-244.

Rupley, A.E. (1997) Pp. 278-279 in Common diseases: manual of avian practice. Philadelphia: Saunders.

Sanz, V. and Grajal, A. (1998) Successful reintroduction of captive-raised yellowshouldered Amazon parrots on Margarita Island, Venezuela. Conserv. Biol. 12: 430-441.

Schubot, R.M., Clubb, K.J. and Clubb, S.L. (1992) Pp. 231-234 in Psittacine aviculture. Avicultural Breeding and Research Center, Loxahatchee, Florida.

Silva, T. (1989) A monograph of endangered parrots. Pickering, Ontario, Canada: Silvio Mattacchione.

Snyder, N.F.R., Koenig, S.E., Koschmann, J., Snyder, H.A. and Johnson, T.B. (1994) Thickbilled parrot releases in Arizona. Condor 96: 845-862.

Soulé, M. (1987) Viable populations for conservation. Cambridge, U.K.: Cambridge University Press.

Taylor, R.H. (1985) Status, habits and conservation of Cyanoramphus parakeets in the New Zealand region. Pp. 195-211 in P. J. Moors, ed. Conservation of island birds. Cambridge, U.K.: International Council for Bird Preservation (Techn. Publ. 3).

Tully, T.N. (1993) Clinical aspects of companion bird Chlamydial infections. Semin. Avian Exotic Pet Med. 2: 157-260.

White, D.O. and Fenner, F. (1987) Medical virology 3rd edn. Orlando, FL: Academic Press.

Wiley, J.W., Snyder, N.F.R. and Gnam, R.W. (1992) Reintroduction as a conservation strategy for parrots. Pp. 165-200 in S.R. Beissinger and N.F.R. Snyder, eds. New World parrots in crisis. Washington, D.C.: Smithsonian Institution Press.

Woolham, F. (1987). Pp. 179-180 in The handbook of aviculture. Poole, Dorset, U.K.: Blandford Press.

DAVID A. OEHLER ${ }^{1}$, MARK CAMPBELL, EDWARD J. MARUSKA and STEVE MALOWSKI

Cincinnati Zoo \& Botanical Garden, 3400 Vine Street, Cincinnati OH, 45220, USA

\section{DAVID BOODOO}

No. 23 Rousseau, St. Sangre Grande, T.W.I./Forestry Division, Wildlife Section, Land and Marine Resources, Ministry of Agriculture, Farm Road, St. Joseph, Trinidad, West Indies.

\section{BERNADETTE PLAIR}

CREW, Cincinnati Zoo \& Botanical Garden, 3400 Vine Street, Cincinnati, OH, 45220, USA

\footnotetext{
${ }^{1}$ Author for correspondence, e-mail: sinornis513@aol.com
} 
GUPTE LUTCHMEDIAL

Safeway Access Ltd., Chooto Road, El. Scorro South, San Juan, T.W.I./Manatee Conservation Trust, Trinidad, West Indies

SHAM RAMSUBAGE

Picton Extension, Ramoutar Village, Sangre Grand, T.W.I.

Received 16 May 2000; revision accepted 9 January 2001 